\title{
CYP2D6*12 Allele
}

National Cancer Institute

\section{Source}

National Cancer Institute. CYP2D6*12 Allele. NCI Thesaurus. Code C46045.

Human CYP2D6*12 allele is located in the vicinity of 22q13.1 and is approximately $4 \mathrm{~kb}$ in length. This allele, a variant form of the CYP2D6 wild-type allele, encodes cytochrome P450 2D6*12 protein. The CYP2D6*12 allele exhibits a clinically-relevant SNP (g.124G>A) in exon 1 that results in a G42R coding change. This alteration in protein sequence abolishes the enzymatic activity of the cytochrome P450 2D6*12 protein. 